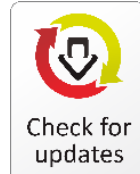

updates

Article Type: Research Paper

\title{
Has IFRS improved Accounting Quality in Indonesia? A Systematic Literature Review of 2010-2016
}

\author{
Ersa Tri Wahyuni, Gina Puspitasari, Evita Puspitasari
}

\begin{abstract}
:
Research aims: International Financial Reporting Standard or IFRS has been promoted as globally-acceptable accounting standard. Previous studies indicate that in developed countries, in Europe for instance, IFRS implementation demonstrates a positive effect and tendency towards better accounting quality. This research aims to discover the effect of IFRS implementation in Indonesia through studying relevant journal articles published between 2010-2016. The present study provides an overview of how the standard is implemented in the country.

Design/Methodology/Approach: Data were collected from 168 research published in the observed period by conducting a structured literature review. Research findings: The results show that research articles on the impact of IFRS in Indonesia is more dominant (53.66\%) than that on implementation and issues (23.17\%) and the development of IFRS convergence process (23.17\%). Out of the 189 frequencies from sampled studies on the impact of IFRS convergence in Indonesia, the study of value relevant $(25.39 \%)$ and earnings management (24.35\%) is the most common method used in discussing the IFRS impact. In general, IFRS convergence has positive impact to the quality improvement of financial statements, as evidenced by the increased relevance of value, the quality of accounting information, the quality of profit, and the company's financial performance as well as the decreasing earnings management practices. Theoretical contribution/Originality: This research contributes to the development of knowledge about IFRS research and the impact of IFRS convergence in a developing country.

Practitioner/Policy implication: The results of this study indicate the overall impact of IFRS in Indonesia that can be used as foundation for further research. This study can be used as a reference for future studies, to determine what topics have not been addressed in this study or what topics can be further investigated. Also, regulator can use my findings as a reference, for understanding the benefits of IFRS implementation in Indonesia and for making improvements in their policy and regulations.

Research limitation/Implication: Some papers analysed in this paper come from the proceedings of Simposium Nasional Akuntansi (SNA). As proceedings may not be as rigorous as publication in the academic journal, SNA remains as the most prestigious accounting conference in Indonesia which invites high quality papers. Keywords: IFRS; Indonesia; Literature Review; Accounting Quality
\end{abstract}




\section{Introduction}

Financial report is an important instrument in evaluating company's performance. The Conceptual Framework of Financial Report with Financial Accounting Standard (DSAKIAI, 2015) states that a financial report serves to provide financial information of the reporting entity which is useful for current and future investors, loan provider, and other creditors in making decisions regarding resources provision to the entity. The general accounting rules and principles play important role in the process of compiling and presenting financial information to external users who rely on such information to make decisions (Ahmed, Chalmers, \& Khlif , 2013).

The fact is, accounting standard in each nation in the world is different. According to Ball (2006), this is because accounting is shaped by the economic and political factors. In line with that, Balsari and Varan (2014) note that the development of accounting system and practice in a nation is a reflection of its economic development and its legislative process. To improve comparability and quality of financial report in global market, it is necessary to implement internationally applied accounting standard (Yurisandy \& Puspitasari, 2015). In response to this problem, the International Accounting Standard Committee (IASC) produced the International Accounting Standard (IAS). In addition, the International Accounting Standard Board (IASB) issued International Financial Reporting Standards (IFRS) as the new standard of accounting and financial reporting to bridge the gap of standard in various nations.

The IFRS rules, which use principle-based standards, are expected to improve financial transparency, quality, and comparability, which in turn will reduce the problems in accounting practices and the costs of comparing investment risks and opportunities in the global market (Daske, 2006). It is also said that the principles may diminish alternatives and limit management opportunities, as well as require better accounting measures to reflect a company's economic position and performance (Barth, Landsman, \& Lang, 2008). The implementation of fair value is considered as the greatest challenge for accounting professionals, who have never practice fair value implementation in their Indonesian Financial Accounting Standards (PSAK) (Wahyuni, 2011). Thus, improvement in accounting professionals' capability is necessary. In Indonesia, IFRS is implemented in convergence, i.e. the changes in PSAK are applied gradually. As the only G20 member nation in the Southeast Asia, Indonesia faces the consequences of implementing IFRS in its financial accounting standards, as agreed by all G20 member countries (Wahyuni, 2011).

IFRS implementation is not a simple task, especially for a big nation such as Indonesia. It warrants readiness from all stakeholders, including regulation makers, actuaries and evaluating services, business entities, and the government. Unpreparedness of financial industry, particularly the banking industry, to adopt the financial instrument accounting standards of PSAK 50 and PSAK 55 (the financial instrument accounting standards adopted from IAS 32 and IAS 39) has caused IFRS implementation to be postponed. It was planned to be effective per 1 January 2009, but the actors of industry demand it to 
be postponed until 1 January 2010 (Eng \& Tri, 2012). This results in the delay of IFRS full convergence implementation, from 2010 to 2012.

IFRS convergence in Indonesia is an interesting and actual topic to be studied. Based on the literature review, there have been many research articles discussing this matter from various points of view. The present study aims to discover the trend of IFRS convergence studies in Indonesia during the period of 2010-2016, the effect of IFRS convergence implementation on financial reporting quality in Indonesia, and the differences of findings in various studies. The paper contributes to the literarure and accounting business spractice in several ways. First, this paper provides the literature map of IFRS research over important time in Indonesia which can guide further researchers in exploring less-researched topic area in IFRS studies. Second, this paper provides insights to the investor and preparers about the impact of IFRS convergence in Indonesia to the quality of financial statements. Third, this paper categorised the research methodology of past publications which may encourages further methodology innovation in the future research of IFRS and theory, include the principles of Islam in legislation, and the fatwa issued by the authorized institution.

\section{Literature Review and Focus of Study}

The IAS, followed by IFRS, as the international accounting standard is expected to generate higher quality in accounting information. However, the implementation of the standard produces varied results. For instance, in terms of IFRS and earning management, the implementation of IFRS is expected to reduce the practice of profit management occurring in almost every company in the world, as found by Barth, et al (2008), Zeghal, Chtourou, \& Fourati (2012), Christensen, Lee, Walker, \& Zeng (2015). However, other studies (Lang, Raedy, \& Wilson (2006), Van Tendeloo and Vanstraelen (2005), Callao and Jarne (2010)) found contradictive results, in which earning management increased after the adoption of IFRS.

Adopting IFRS is an accounting 'language' which is globally accepted to improve comparability of financial reporting, so that it may facilitate the limitation of capital flow and reduce cost of capital (Lee, Walker, \& Christensen, 2008). This is in line with the statement of former head of SEC, Arthur Levitt (1998, in Lee, et al, 2008), that a high quality standard will reduce the cost of capital.

The findings concerning the relationship between IFRS implementation and cost of capital are varied, including the decrease of cost of capital (Daske, Hail, Leuz, \& Verdi, 2008), the increase of cost of capital (Daske, 2006), and no decrease or increase of cost of capital (Cuijpers \& Buijink, 2005). The decrease of cost of capital is found in countries whose incentives in financial reporting are relatively low, such as Greece and Portugal. Meanwhile, in countries with high incentives in financial reporting, particularly in UKbased companies, cost of capital increase is found (Christensen, Lee, \& Walker, 2007; Lee, et al, 2008). 
Value-relevance studies determine whether an accounting number is useful for valuing the firm by investigating whether the accounting number is associated with stock prices (Holthausen \& Watts, 2001). Value-relevance is expected to increase after IFRS implementation. The increase in value relevance is found in studies by Barth, et al (2008); Christensen, et al (2015); and Collins, Maydew, \& Weiss (1997), particular to book value per share. Meanwhile, a decrease in value relevance is found in studies by Zeghal, et al (2012) and Collins, et al (1997), particular to earnings per share.

Conservatism is expressed with the golden rule of "anticipate no profits but anticipate all losses" (Bliss, 1924, in Basu, 1997). According to Basu (1997), conservatism is interpreted as accountants' tendency to require higher level of verification to admit good news, than to admit bad news, in financial report. After the implementation of IFRS, it is expected that such accounting conservatism will decrease, as found by Zeghal, et al (2012). However, Gassen and Sellhorn (2006) found that companies that implement IFRS are more conservative than those that implement German-GAAP (HGB). IFRS become an apparent global accounting standard after European Union adopted the standard for consolidated financial statement in the European capital market in 2005. The decision triggered a contagious effect to Australia and the Phillipines who also adopted IFRS in 2005. The next milestone for IFRS worldwide adoption was after 2007 when US SEC allowed foreign issuers submit IFRS based financial report in the US Capital Market. This decision encouraged other countries to make decision to adopt IFRS in 2008, Including Indonesia.

The decision to adopt IFRS in Indonesia was announced at December 2008 by the Institute of Indonesia Chartered Accountants (IAI) to be implemented in 2012 (first phase of IFRS adoption). Starting in 2009, The Indonesian Accounting Standard Board (Dewan Standar Akuntansi Keuangan/DSAK), the board funded by the IAI, issued various IFRS standards to replace the local standards. At 2012, DSAK has issued most of the accounting standards mirroring their IFRS standard as issued at 2009 by IASB. The convergence model of Indonesia creates 3-year gap between local standards and IFRS. This gap was being reduced in 2015 where DSAK adopted the 2014 version of IFRS (second phase of IFRS adoption). Almost all IFRS was adopted except for IAS 41 Agriculture which was adopted in 2018 together with the related amendment of IAS 16 on bearer's plants. However based on this important milestone, this study choose the year 2010 (one year after the announcement of IFRS adoption) to 2016 (one year after the second phased of IFRS adoption) as the period of the study.

Although Indonesia adopted most of IFRS standards, DSAK reserved its rights to issued local Indonesian standard whenever necessary and when IFRS can not accommodate the local demand of a specific transactions. For example DSAK issued the interpretation of IAS 41 Investment Property (ISAK 31) in 2015 due to the mixed interpretation of the standard for telecommunication tower among Indonesia's listed companies. DSAK also issued a specific standard (PSAK 70) on how to account the addition of asset from the Tax Amnesty programme in 2015. Nevertheless, after 2015 Indonesian local standards are very similar to IFRS, except for few standards and interpretations. 
In Indonesia, research literature study concerning IFRS is unavailable. Therefore, the present study uses previous researches on literature review study as its reference, including Balsari and Varan (2014) who studied IFRS implementation in 2005-2014 in Turkey, Ahmed, et al (2013) who studied the effect of financial reporting after IFRS implementation, and Lourenco and Branco (2015) who studied accounting articles indexed in Social Sciences Citation Index (SSCI).

\section{Research Method}

The present study employs a qualitative method with thematic approach to structured literature review, utilizing secondary data gathered through literature data collection techniques on research articles concerning IFRS in Indonesia. The sample articles are collected from Simposium Nasional Akuntansi (SNA), Emerald in Sight, ProQuest, Science Direct, Portal Garuda, and google scholar. The research articles are gathered, selected, and categorized using interpretative paradigm method. The articles are then analyzed in-depth, in terms of The effect of IFRS convergence in Indonesia based on thematic categories, to generate conclusions that can be used as a direction and reference for future studies.

SNA conference proceedings were chosen as one of the database to collect sample because SNA is the most reputable accounting conference in Indonesia. Every year the conference only accet about $10 \%$ from total submissions, far more competitive than most of national academic journal. However, we understand that presenters at SNA may then send the revised version of the paper to the academic journal, thus we do not double counted and always choose the journal version.

The sampling technique employed in this study is the nonprobability sampling, using systematic sampling technique. The sample is selected based on the following criteria:

1. Research articles are taken from SNA and non-SNA publications, including Emerald in Sight, ProQuest, Science Direct, Portal Garuda, and google scholar.

2. Research articles are found through a search with the keywords of IFRS and Indonesia. To filter more relevant articles, other categories of search are added, particular to each source of journal, using advanced search option such as year duration and type of publication

3. Research articles are published between 2010 and 2016.

4. For Portal Garuda national database, we try to attract good quality papers, thus we eliminate academic journals that are not accredited by the Ministry of Higher Education.

5. For Google Scholars we eliminated all undergraduate and postgraduate thesis, manuscripts, magazine articles and also IFRS papers where the focus is not about Indonesia

6. All the sampled then is carefully checked for duplication in other database. From SNA Proceedings, if the paper then published in other journal, we only include the journal version of the paper. 


\section{Result and Discussion}

\section{Classification of Article Categorization}

The research articles that become the sample are then manually analyzed in detail to extract various information which cannot be obtained directly just by looking at the title. The manual analysis is conducted by checking the abstract. Should the information included in the abstract has not yielded the required information, the content of the article is checked. The classification of the articles in this study is adopted from previous study by Weerakkody, Dwivedi, and Irani (2009).

\section{Article Classification Based on Year of Publication}

The findings (illustrated in Table 1 ) show that the number of published article significantly increases in 2012. The most number of article published is in 2014 (37 articles), followed closely by 2014 (33 articles) and 2016 ( 25 articles). The increase in the number of published article in 2012 and subsequent years indicates an increase of interest and activity in research, as the full convergence of IFRS is implemented in Indonesia since 2012.

Table 1 Article Classification Based on Year of Publication

\begin{tabular}{rrr}
\hline Year & Count $(n=164)$ & $\%$ of 164 \\
\hline 2010 & 10 & 6.10 \\
2011 & 14 & 8.54 \\
2012 & 23 & 14.02 \\
2013 & 22 & 13.41 \\
2014 & 37 & 22.56 \\
2015 & 33 & 20.12 \\
2016 & 25 & 15.24 \\
\hline
\end{tabular}

\section{Article Classification based on Analysis Unit}

The result of articles exploration based on analysis unit (Table 2) shows that majority of the researches (107 articles) studied various issues on organisation/firm analysis unit. 25 articles use non-empirical data analysis unit to describe IFRS theoretically. 19 articles employ accounting practitioner analysis unit; the practitioners consisted of auditors, accountants, lecturers, and students of accounting department. There are 12 articles that compare IFRS implementation in various countries, and only 1 article that discusses the accounting system needed in IFRS implementation. 
Table 2 Unit of Analysis

\begin{tabular}{lrr}
\hline Unit of analysis & Count $(\mathbf{n}=164)$ & \% of 164 \\
\hline Organisation/firm & 107 & 65.24 \\
Non-empirical data (theory) & 25 & 15.24 \\
Accounting practitioner & 19 & 11.59 \\
Country & 12 & 7.32 \\
Systems & 1 & 0.61 \\
\hline
\end{tabular}

\section{Article Classification based on Its Research Paradigm}

The classification based on research paradigm (Table 3 ) shows that the most dominant paradigm is positivism, which is implemented in 118 articles. The next dominant research paradigm is the descriptive/conceptual/theoretical research paradigm, employed in 38 articles that focus on literature review. The articles that belong to this category are those that do not belong to either the positivism paradigm or interpretive paradigm. The last category is the interpretive research paradigm (8 articles) which contain researchers' interpretation concerning the issues of IFRS convergence in Indonesia.

Table 3 Research Paradigm

\begin{tabular}{lrr}
\hline Research Paradigm & Count $(n=164)$ & $\%$ of 164 \\
\hline Positivism & 118 & 71.95 \\
Descriptive/conceptual/theoretical & 38 & 23.17 \\
Interpretive & 8 & 4.88 \\
\hline
\end{tabular}

\section{Article Classification based on Research Methodology (Empirical vs. Non-Empirical)}

139 articles are found to belong to the category of empirical research method (Table 4). The articles that belong to this category are those that utilize data, conduct observation or measurement, and tested to form conclusion. 25 articles belong to the category of non-empirical research method because they focus more on ideas and concepts.

Table 4 Research Methodology (Empirical vs. Non-Empirical)

\begin{tabular}{lrr}
\hline Research Methodology & Count $(n=164)$ & $\%$ of 164 \\
\hline Empirical & 139 & 84.76 \\
Non-empirical & 25 & 15.24 \\
\hline
\end{tabular}

\section{Article Classification based on Research Methodology (Quantitative vs. Qualitative)}

Quantitative approach dominates the research method of the sample (119 articles; see Table 5). Followed by qualitative approach ( 44 articles) and mixed-method approach (1 article). The study with qualitative method is seldom found, even though there are great potentials that this method can discover. 
Table 5 Research Methodology (Quantitative vs. Qualitative)

\begin{tabular}{lrr}
\hline Research Methodology & Count $(n=164)$ & $\%$ of 164 \\
\hline Quantitative & 119 & 72.56 \\
Qualitative & 44 & 26.83 \\
Mixed & 1 & 0.61 \\
\hline
\end{tabular}

\section{Research Methods used in the Articles}

Table 6 displays the research methods used in the articles, categorized into 6 research approach. Most of the articles (107 articles) employ secondary data analysis approach. 26 articles employ conceptual/literature analysis/literary study method, 15 articles use survey, 9 articles use interview, 6 articles employ case study approach, and 1 article employ content analysis approach.

Table 6 Research Methods

\begin{tabular}{lrr}
\hline Research Method & Count $(\mathbf{n}=164)$ & $\%$ of 164 \\
\hline Secondary data analysis & 107 & 65.24 \\
Library research/literature & 26 & 15.85 \\
analysis/conceptual method & & \\
Survey & 15 & 9.15 \\
Interview & 9 & 5.49 \\
Case study & 6 & 3.66 \\
Content analysis & 1 & 0.61 \\
\hline
\end{tabular}

\section{Classification of Article based on IFRS Convergence Stages}

Article classification in the present study adopts the classification in Balsari and Varan (2014) who studied IFRS implementation in Turkey. The classification consists of IFRS convergence implementation and issues in Indonesia (38 articles, 23.17\%), IFRS convergence development in Indonesia (38 articles, 23.17\%), and the effect of IFRS convergence in Indonesia ( 88 articles, $53.66 \%$ ). The detailed description is as follow:

a. IFRS convergence implementation and issues in Indonesia

In table 7, Themes in IFRS Convergence Implementation and Issues in Indonesia category, the most common theme is factors affecting IFRS adoption (14 articles), such as good corporate governance, quality of regulations, and local accounting standards, the role of culture and law enforcement, company characteristics, and Indonesia's participation in international institutions. This theme is followed by the preparation in accounting education (11 articles), including the need to develop accounting textbooks, accounting curriculum that conforms to IFRS regulations, facilities and infrastructures for teaching-learning process, students' and lecturers' preparedness to learn IFRS materials, and the need of training in the effort of improving teachers' competence. Practitioners' (accountants, auditors, lecturers, and students) perception is the next common theme ( 8 articles), followed by the determining factors of implementation success ( 4 articles), i.e. good accounting 
system and stakeholders' (regulators, auditors, preparer, and university) support. The last theme is the different regulations of IFRS and taxation (1 article).

Table 7 Themes in IFRS convergence implementation and issues in Indonesia

\begin{tabular}{lcc}
\hline Theme & Count $(\boldsymbol{n}=\mathbf{3 8})$ & $\%$ of 38 \\
\hline Factors affecting IFRS adoption & 14 & 36.84 \\
Preparation in accounting education & 11 & 28.95 \\
Practitioner's perception & 8 & 21.05 \\
Factors of implementation success & 4 & 10.53 \\
Different regulations of IFRS and taxation & 1 & 2.63 \\
\hline
\end{tabular}

b. IFRS convergence development in Indonesia

In Table 8 the theme of fair value implementation is dominant 20 articles, 52.63\%). This is followed by the discussion on harmonization of IFRS and Financial Accounting Standards (SAK) (9 articles, 23,68\%), and comparison of IFRS adoption in Indonesia with other countries (4 articles, 10,53\%) which consists of the discussion on socioeconomic effects of the countries, practitioners' perception in each country, role of culture in each country, and government quality of the countries. Meanwhile, the themes of IFRS conformity to SAK ETAP ( 3 articles) and to shariah accounting (2 articles) are seldom found.

Table 8 Themes in IFRS convergence development in Indonesia

\begin{tabular}{lcc}
\hline Theme & Count $(n=38)$ & $\%$ of 38 \\
\hline Fair value implementation & 20 & 52.63 \\
Harmonization of IFRS and SAK & 9 & 23.68 \\
$\begin{array}{l}\text { Comparison of IFRS adoption in Indonesia with other } \\
\text { countries }\end{array}$ & 4 & 10.53 \\
IFRS conformity to SAK ETAP & 3 & 7.89 \\
IFRS conformity to sharia accounting & 2 & 5.26 \\
\hline
\end{tabular}

c. The effect of IFRS convergence in Indonesia

Classification in this category is not conducted based on themes, like the previous two categories. Rather, it is based on the variables affected by the IFRS implementation in Indonesia, which allows or multiple variables in an article journal. From 88 articles, 193 frequencies are found, with 17 categories which will be detailed in the next part.

\section{The Effect of IFRS Convergence in Indonesia}

The study concerning IFRS convergence effects in Indonesia on 88 articles yields 193 frequencies, classified to 17 categories (see Figure 1 Article Categories on The effect of IFRS convergence in Indonesia in 2010-2016). Categories 1-5 will be discussed per item, while categories 6-17 will be discussed altogether because the numbers are not significant. 


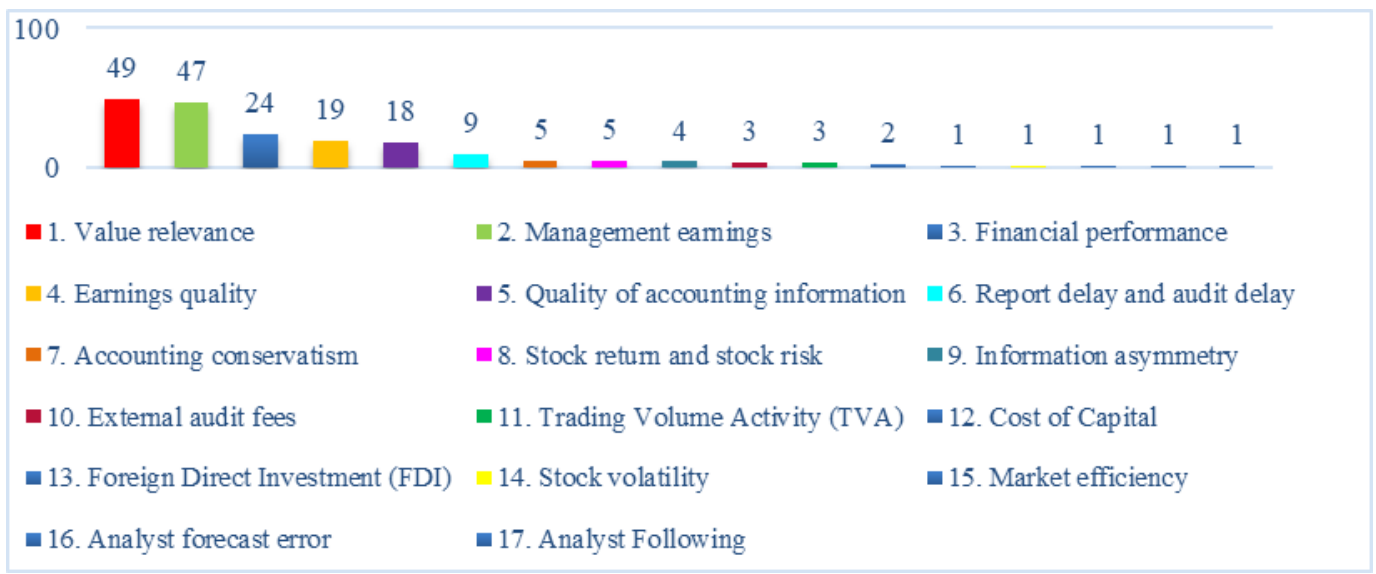

Figure 1 Article Categories on The effect of IFRS convergence in Indonesia in 2010-2016

\section{a. The Effect of IFRS Convergence in Indonesia on Value Relevance}

Study on value relevance is the most frequently found with 49 frequencies ( $25.39 \%$ of the total) in which there are 36 frequencies of positive effect (73.47\%), 12 frequencies of no effect (24.49\%), and 1 frequency of negative effect (2.04\%). These findings support the assumption that IFRS implementation is expected to have positive effects on value relevance. The most frequently used research period is 4 years (19 frequency) with varied conclusion from positive effect to no effect. The research period of 7 years or more shows a consistent result of positive effect. Meanwhile, based on number of sample, the category of 300-400 sample shows more consistent positive effect (See, Appendix Table A).

Table 9 Measurement Variable Used in the Study of the effect of IFRS convergence in Indonesia on Value Relevance in 2010-2016

\begin{tabular}{|c|c|c|c|c|c|}
\hline No & IFRS Measurement Variable & $\begin{array}{l}\text { Positive } \\
\text { Effect }\end{array}$ & $\begin{array}{l}\text { Negative } \\
\text { Effect }\end{array}$ & $\begin{array}{c}\text { No } \\
\text { Effect }\end{array}$ & $\begin{array}{l}\text { Total } \\
\text { Frequency }\end{array}$ \\
\hline 1 & IFRS as dummy variable in the analysis & 3 & - & 1 & 4 \\
\hline 2 & $\begin{array}{l}\text { IFRS adoption year as the dividing time line } \\
\text { for pre-post comparison }\end{array}$ & 26 & 1 & 10 & 37 \\
\hline 3 & $\begin{array}{l}\text { PSAK Revised } 2007 \text { which is effective } \\
\text { January 1, } 2008 \text { (PSAK } 13 \text { Investment } \\
\text { properties, PSAK } 16 \text { Property Plant and } \\
\text { Equipment, PSAK } 30 \text { Leases) as dummy } \\
\text { variable }\end{array}$ & 2 & - & - & 2 \\
\hline 4 & Adjustment BEV and NI with IFRS rules & 1 & - & - & 1 \\
\hline 5 & PSAK 19 Goodwill & 1 & - & - & 1 \\
\hline 6 & PSAK 30 Leases & 3 & - & - & 3 \\
\hline \multirow[t]{2}{*}{7} & $\begin{array}{l}\text { Percentage of compliance to IFRS over the } \\
\text { years }\end{array}$ & - & - & 1 & 1 \\
\hline & Total Frequency & 36 & 1 & 12 & 49 \\
\hline
\end{tabular}


From Table 9, it can be seen that IFRS as the dividing time line for pre- and postcomparison analysis is dominantly used in measuring value relevance of financial reporting (37 frequencies), with 26 frequencies of positive effect, indicating that the financial report becomes more relevant after IFRS implementation. On the category of IFRS as dummy variable in measuring value relevance of financial reporting (4 frequencies), three frequencies show positive effect.

Implementation of PSAK Revision 2007 effective on January 1, 2008, which is PSAK 13 Investment Property, PSAK 16 Fixed Assets, and PSAK 30 Leases to 100 non-bank companies, non-bank financial institutions, securities, and insurers, show the conclusion of an increase in the value relevance of earnings and book value equity (Dewi and Kaseh, 2011).

In its relation to the implementation of PSAK 19, which is adopted from IAS 38, the implementation of fair value has an effect on the improvement of goodwill value relevance (Iswaraputra \& Farahmita, 2013). Concerning PSAK 30 (2011) Leases, IFRS implementation, particularly on leases accounting standards, is improving value relevance of accounting information, as proven by the value relevance of PSAK 30 (2007 Revision) which is higher than PSAK 30 (1994) and PSAK 30 (2011 Revision) is higher than PSAK 30 (2007 Revision) (Sitopu \& Wardhani, 2014).

\section{b. The Effect of IFRS Convergence in Indonesia on Earnings Management}

The study on earnings management is on the second most frequent study with 47 frequencies (24.35\% of the total), with 19 frequencies of negative effects $(40.43 \%), 15$ frequencies of no effect (31.91\%), and 13 frequencies of positive effect (27.66\%). The more frequent negative effect supports the assumption that IFRS implementation will reduce earnings management practices. In these cohort of studies, the studies use the proxy of earnings management (e.g discretionary accruals) as the dependent variables and IFRS adoption as one of the the independent variables.

Based on the period of research, there are 21 frequencies whom authors use 4 year observation period with varied results, from negative effect, positive effect, to no-effect. When the authors use the 8 year observation period or more, the studies shows more consistent result of negative effect. Meanwhile, based on the number of sample, the 400-500 sample shows the most frequency ( 14 frequencies), with varied conclusion. It means that it cannot be concluded what number of sample will produce consistent conclusion (see Appendix Table B). The use of IFRS as measurement variable is detailed in Table 10.

From Table 10, it can be seen that IFRS as comparison limit pre- and post IFRS implementation is the most dominantly used in measuring earnings management practices ( 21 frequencies). The distribution of the effect is equal, 7 frequencies of negative effect, positive effect, and no effect, each. Meanwhile, IFRS as dummy variable (11 frequencies) consists of 7 frequencies of negative effect and 2 frequencies of positive effect and no effect, each. 
Table 10 Measurement Variables Used in the Study of the Effect of IFRS Convergence in Indonesia on Earnings Management in 2010-2016

\begin{tabular}{|c|c|c|c|c|c|}
\hline No & IFRS Measurement Variable & $\begin{array}{l}\text { Negative } \\
\text { Effect }\end{array}$ & $\begin{array}{l}\text { Positive } \\
\text { Effect }\end{array}$ & $\begin{array}{l}\text { No } \\
\text { Effect }\end{array}$ & $\begin{array}{l}\text { Total } \\
\text { Frequency }\end{array}$ \\
\hline 1 & Accrual Earnings Management & 8 & 5 & 8 & 21 \\
\hline a & IFRS as dummy variable & 2 & 2 & 2 & 6 \\
\hline$b$ & $\begin{array}{l}\text { IFRS adoption year as the dividing time line } \\
\text { for pre-post comparison }\end{array}$ & 5 & 3 & 5 & 13 \\
\hline c & Adoption of IFRS 8 as PSAK 5 (2009) & - & - & 1 & 1 \\
\hline d & $\begin{array}{l}\text { Implementation of PSAK 50/55 (2006 } \\
\text { Revision) }\end{array}$ & 1 & - & - & 1 \\
\hline 2 & Real Earnings Management & 4 & 7 & 1 & 12 \\
\hline a & IFRS as dummy variable & 3 & - & - & 3 \\
\hline$b$ & IFRS as pre-post comparison limit & 1 & 4 & 1 & 6 \\
\hline c & $\begin{array}{l}\text { Scale based on comparison of IFRS } \\
\text { adoption in local accounting standards }\end{array}$ & - & 3 & - & 3 \\
\hline 3 & Income smoothing & 5 & - & 1 & 6 \\
\hline a & IFRS as dummy variable & 2 & - & & 2 \\
\hline $\mathrm{b}$ & IFRS as pre-post comparison limit & 1 & - & 1 & 2 \\
\hline c & IGAAP index surveyed by CLSA in 2010 & 1 & - & - & 1 \\
\hline d & $\begin{array}{l}\text { Scale based on comparison of IFRS } \\
\text { adoption in local accounting standards }\end{array}$ & 1 & - & - & 1 \\
\hline & Total Frequency & 17 & 12 & 10 & 39 \\
\hline
\end{tabular}

In the implementation of IFRS 8 adoption as PSAK 5 (2009) on operational segment as measurement variable, it is found that companies become more transparent in disclosing information of company segments on post-IFRS report, so that the information is more valid and able to minimize managers' desire to manipulate profit at segment level (Wijayanti \& Rusiti, 2014).

The implementation PSAK 50 (2006 Revision) on Financial Instrument: Presentation and Disclosure, adopted from IAS 32, and the implementation of PSAK 55 (2006 Revision) on Financial Instrument: Acknowledgement and Measurement, adopted from IAS 39, is proven to reduce accrual income management because the determination of problematic credit becomes more objective, stricter regulations on financial instrument reclassification, and more detailed and comprehensive disclosure requirement (Nurazmi, et al, 2015).

\section{c. The Effect of IFRS Convergence in Indonesia on Company Financial Performance}

The study on company financial performance is found in 24 frequencies $(12.44 \%$ of the total) with 11 frequency of positive effect (45.83\%), 4 frequency of negative effect $(16,67 \%)$, and 9 frequency of no effect $(37.50 \%)$. This finding support the assumption that IFRS implementation will have positive effect on company financial performance. It is most commonly found in the 2 year period research (12 frequencies), in which 
positive effect dominates the result ( 5 frequencies; $41.67 \%$ ). Meanwhile, in the 100-200 sample, 17 frequencies are found, 9 of which (52.94\%) are positive effect (see Appendix Table C).

The utilization of IFRS as measurement variable is detailed in Table 11.

Table 11 Measurement Variable used in the Study of the Effect of IFRS Convergence in Indonesia on Company Financial Performance in 2010-2016

\begin{tabular}{|c|c|c|c|c|c|}
\hline No & IFRS Measurement Variable & $\begin{array}{l}\text { Positive } \\
\text { Effect }\end{array}$ & $\begin{array}{l}\text { Negative } \\
\text { Effect }\end{array}$ & $\begin{array}{c}\text { No } \\
\text { Effect }\end{array}$ & $\begin{array}{l}\text { Total } \\
\text { Frequency }\end{array}$ \\
\hline 1 & IFRS as dummy variable & 3 & 1 & 3 & 7 \\
\hline 2 & $\begin{array}{l}\text { IFRS adoption year as the dividing time line } \\
\text { for pre-post comparison }\end{array}$ & 5 & 1 & 4 & 10 \\
\hline 3 & $\begin{array}{l}\text { PSAK Revised } 2007 \text { which is effective } \\
\text { January 1, } 2008 \text { (PSAK } 13 \text { Investment } \\
\text { properties, PSAK } 16 \text { Property Plant and } \\
\text { Equipment, PSAK } 30 \text { Leases) as dummy } \\
\text { variable }\end{array}$ & 3 & 2 & - & 5 \\
\hline \multirow[t]{2}{*}{4} & PSAK 16 (2007 Revision) Fixed Asset-IAS 16 & - & - & 2 & 2 \\
\hline & Total Frequency & 11 & 4 & 9 & 24 \\
\hline
\end{tabular}

In studies that use IFRS as dummy variable (7 frequencies), 3 frequencies $(42,86 \%)$ show positive effect. In IFRS as pre-post comparison limit (10 frequencies), 5 frequencies (50.00\%) show improvement in financial performance, as evident in the increase of liquidity ratio, rentability, and solvability of Capital Adequacy Ratio (CAR), Return on Assets (ROA), Return on Equity (ROE), Operating Profit Margin (OPM), Market Value Book Value (MVBV), Debt to Equity (DER), Price to Book Value (PBV), Debt to Asset Ratio (DAR), and Loan to Assets Ratio (LAR).

Research on the individual of new standard to the company performance such as standard for investment property and property plant equipment shows mixed result. Some research shows that the adoption of new standard of PSAK 13, PSAK 16 and PSAK 30 have positive effect ( 3 frequency) to the company's performance proxied by financial ratios while some shows negative effect (2) and no effect (2).

\section{d. The Effect of IFRS Convergence in Indonesia on Earnings Quality}

The paper we analyse in this section put Earnings Quality as the dependent variables and mostly use ERC (Earning Response Coeficient) to calculate Earnings Quality. Studies on earnings quality are found in 18 frequencies (9.33\% of the total), with 10 frequencies of positive effect (55.56\%) and 8 frequencies of no effect (44.44\%). This finding supports the assumption that IFRS implementation is expected to have positive effect on earnings quality. The most frequently found period of research is the 7 year period $(6$ frequencies), in which positive effect and no effect are of 3 frequencies each. In other words, it cannot be concluded whether or not longer period will result in positive effect. Similarly, the most frequently found sample is $200-300$ sample (7 frequencies), in which 3 frequencies of positive effect and 4 frequencies of no effect. 400-500 sample and more than 500 sample should be considered for future research (see Appendix Table E). 
The use of IFRS as measurement variable affects the findings of the studies. It is detailed in Table 12.

Table 12 Measurement Variables Used in the Study of the Effect of IFRS Convergence in Indonesia on Earnings Quality in 2010-2016

\begin{tabular}{|c|c|c|c|c|c|}
\hline No & IFRS Measurement Variable & $\begin{array}{c}\text { Positive } \\
\text { Effect }\end{array}$ & $\begin{array}{c}\text { Negative } \\
\text { Effect }\end{array}$ & $\begin{array}{c}\text { No } \\
\text { Effect }\end{array}$ & $\begin{array}{c}\text { Total } \\
\text { Frequency }\end{array}$ \\
\hline 1 & IFRS as dummy variable & 1 & - & 1 & 2 \\
\hline 2 & $\begin{array}{l}\text { IFRS adoption year as the dividing time line } \\
\text { for pre-post comparison limit }\end{array}$ & 6 & - & 4 & 10 \\
\hline 3 & $\begin{array}{l}\text { Scale based on the number of IFRS adoption } \\
\text { in local accounting standards }\end{array}$ & 1 & - & - & 1 \\
\hline 4 & $\begin{array}{l}\text { Accounting standards as dummy variable } \\
\text { categorized based on active year }\end{array}$ & & & & \\
\hline a & $\begin{array}{l}\text { The 2002: } \\
\text { - PSAK } 19 \text { Intangible Assets } \\
\text { - PSAK } 46 \text { Income Tax Accounting } \\
\text { - PSAK } 55 \text { Financial Instrument: } \\
\text { Acknowledgement and Measurement }\end{array}$ & 1 & - & - & 1 \\
\hline b & $\begin{array}{l}\text { The 2004: } \\
\text { - PSAK } 51 \text { Quasi-Reorganization Accounting } \\
\text { - PSAK } 58 \text { Non-Current Assets Held for Sale } \\
\text { and Discontinued Operation } \\
\text { - PSAK } 16 \text { Fixed Assets }\end{array}$ & - & - & 1 & 1 \\
\hline c & $\begin{array}{l}\text { The 2005: } \\
\text { - PSAK } 38 \text { Accounting for Restructuring under } \\
\text { Common Control Entities } \\
\text { - PSAK } 24 \text { Employee Benefits }\end{array}$ & - & - & 1 & 1 \\
\hline$d$ & $\begin{array}{l}\text { The 2006: } \\
\text { - PSAK } 13 \text { Investment Property } \\
\text { - PSAK } 30 \text { Leases }\end{array}$ & 1 & - & - & 1 \\
\hline $\mathrm{e}$ & $\begin{array}{l}\text { The 2008: } \\
\text { - PSAK } 14 \text { PSAK } 14 \text { Provision } \\
\text { - PSAK } 26 \text { Loan Cost }\end{array}$ & - & - & 1 & 1 \\
\hline & Total Frequency & 10 & - & 8 & 18 \\
\hline
\end{tabular}

Out of the 18 frequencies of IFRS effect on earnings quality, it can be seen in Table 13 that IFRS as comparison limit before and after implementation is the most frequently used (10 frequencies), 6 frequencies of those show positive effect on earnings quality. IFRS as pre-post comparison limit and IFRS as dummy variable show positive effect on earnings quality after IFRS implementation. This indicates that the overall implementation of fair value has demonstrated actual information on management performance, so that the users of the financial report can use it to make decision. Meanwhile, other PSAK; i.e. PSAK 51, PSAK 58, PSAK 16 (adopted in 2004), PSAK 38, PSAK 24 (adopted in 2005), PSAK 14, and PSAK 26 (adopted in 2008), have not shown any change in effect on earnings quality (Saito and Sekar, 2011). This study was conducted during the period of IFRS convergence process, which means that it is possible that not all standards have been implemented. It may be beneficial to perform 
similar study nowadays to obtain the most current overview on IFRS adoption after some periods of time.

\section{e. The Effect of IFRS Convergence in Indonesia on Accounting Information Quality}

Some group of papers discussing the impacrt of IFRS adoption to the accounting information quality uses different measurement other than previous categories (Value relevance studies, earnings management, company's financial performance and earning quality). For example one paper use some kind of Penman approach to measure accounting information quality (Praharsini, Rusmana, \& Warsidi, 2015), or another paper use NiCE qualitative characterictic measurement (Yurisandi \& Puspitasari, 2015). These papers are categorized and analysed in this subsection.

Studies on accounting information quality are found in 19 frequencies $(9.84 \%$ of the total), with 14 frequencies of positive effect (73.68\%) and 5 frequencies of no effect (26.32\%). This finding supports the assumption that IFRS implementation will have positive effect on accounting information quality. The quality of accounting information can be seen in the implementation of standards on each account on the financial report, the comparability of the report, and the relevance improvement and honest presentation of accounting information. The two year period of research is found in 13 frequencies, with 9 frequencies of positive effect $(69.23 \%)$. The length of period to measure accounting information quality has no siginificant effect on the conclusion. For instance, the length of financial report can be measured just by studying a two-year measurement before and after IFRS implementation. This can also be seen from the total sample less than 100 (5 frequencies, 38.46\%) (See Appendix D).

Table 13 Measurement Variables Used in the Study of the Effect of IFRS Convergence in Indonesia on Accounting Information Quality in 2010-2016

\begin{tabular}{|c|c|c|c|c|c|}
\hline No & IFRS Measurement Variable & $\begin{array}{l}\text { Positive } \\
\text { Effect }\end{array}$ & $\begin{array}{l}\text { Negative } \\
\text { Effect }\end{array}$ & $\begin{array}{l}\text { No } \\
\text { Effect }\end{array}$ & $\begin{array}{c}\text { Total } \\
\text { Frequency }\end{array}$ \\
\hline 1 & IFRS as dummy variable & 1 & - & 1 & 2 \\
\hline 2 & $\begin{array}{l}\text { IFRS adoption year as the dividing time line for } \\
\text { pre-post comparison }\end{array}$ & 6 & - & 1 & 7 \\
\hline 3 & PSAK 13 Investment Property & - & - & 1 & 1 \\
\hline 4 & PSAK 16 Fixed Assets & 1 & - & - & 1 \\
\hline 5 & PSAK 19 Intangible Assets & - & - & 1 & 1 \\
\hline 6 & $\begin{array}{l}\text { PSAK } 55 \text { Financial Instrument: Acknowledgement } \\
\text { and Measurement }\end{array}$ & t & - & 1 & 1 \\
\hline 7 & $\begin{array}{l}\text { Percentage based on comparisons of IFRS } \\
\text { adoption in local accounting standards }\end{array}$ & 1 & - & - & 1 \\
\hline 8 & $\begin{array}{l}\text { Scale based on implementation level (IASPlus } \\
\text { website) }\end{array}$ & 1 & - & - & 1 \\
\hline 9 & IFRS adoption level & 1 & - & - & 1 \\
\hline 10 & Gray Index & 3 & - & - & 3 \\
\hline & Total Frequency & 14 & - & 5 & 19 \\
\hline
\end{tabular}


From Table 13, it can be seen that IFRS as comparison limit before and after IFRS implementation is dominantly used in measuring accounting information quality ( 7 frequencies), with 7 frequencies of positive effect (36.84\%), indicating that the financial report becomes more relevant after IFRS implementation. Using gray index, a positive effect of IFRS convergence on fixed assets is found, particularly related to PSAK 13 (2011 Revision) Investment Property, PSAK 16 (2011 Revision) Fixed Assets, and PSAK 30 (2011 Revision) Leases (Yanuar, 2013). On studies that use policies as IFRS measurement, it is found that only PSAK 16 Fixed Assets that shows an increase in financial report comparability. The other three: PSAK 13 Investment Property, PSAK 19 Intangible Assets, and PSAK 55 Financial Instruments: Acknowledgement and Measurement do not. On accounting policies that are allowed to choose measurement method, there is no proof of financial report comparability decrease, even though the fair value measurement level is still low because the cost method is still the most dominantly chosen (Khomsatun, 2016).

\section{f. The Effect of IFRS Convergence in Indonesia on Other Factors}

The other factors in this study consist of a combination of categories, in which the frequency of each category is less than $5 \%$. The finding on each category is detailed in Table 14.

Table 14 Comparison of Findings on the Effect of IFRS Convergence in Indonesia on Other Factors

\begin{tabular}{clcccc} 
No & & $\begin{array}{c}\text { Positive } \\
\text { Effect }\end{array}$ & $\begin{array}{c}\text { Negative } \\
\text { Effect }\end{array}$ & $\begin{array}{c}\text { No } \\
\text { Effect }\end{array}$ & $\begin{array}{c}\text { Total } \\
\text { Frequency }\end{array}$ \\
\hline 1 & Report delay and audit delay & 4 & - & 5 & 9 \\
\hline a & Report delay & 2 & - & - & \\
b & Audit delay & 2 & - & 5 & \\
\hline 2 & Accounting conservatism & 2 & 1 & 2 & 5 \\
\hline 3 & Stock return and risk & - & 2 & 3 & 5 \\
\hline a & Stock return & - & - & 3 & \\
b & Stock risk & - & 2 & - & \\
\hline 4 & Information asymmetry & - & 2 & 2 & 4 \\
\hline 5 & External audit fee & 3 & - & - & 3 \\
\hline 6 & Trading Volume Activity (TVA) & 1 & - & 2 & 3 \\
7 & Cost of capital & - & 2 & - & 2 \\
\hline 8 & Foreign Direct Investment (FDI) & 1 & - & - & 1 \\
\hline 9 & Stock volatility & - & 1 & - & 1 \\
\hline 10 & Market efficiency & 1 & - & - & 1 \\
\hline 11 & Analyst forecast error & - & - & 1 & 1 \\
\hline 12 & Analyst following & - & - & 1 & 1 \\
\hline
\end{tabular}




\section{Description of IFRS convergence effect on each factor}

\section{Report delay and audit delay}

Financial reporting and audit are expected to always be timely. However, the implementation of a new standard may affect the timeliness of financial reporting and audit. Studies on such timeliness are found in 9 frequencies (4.66\% of the total). 2 frequencies concerns with report delay show positive effect. This indicates that the implementation of fair value in IFRS requires certain judgment in compiling financial report, which causes the preparation of the report takes longer time (Widyawati and Anggraita, 2013; Silitonga and Farahmita, 2015). The other 7 frequencies concerns with audit delay ( 5 frequencies show no effect and 2 frequencies show positive effect). Two frequency shows a lateness in audit process due to the verification of assessment on fair value implementation of the company. Tracing of audit evidence causes a longer time to publish the audit report (Widyawati and Anggraita, 2013; Lubis, et al, 2015). IFRS as dummy variable dominates the result with 8 frequencies (88.89\%).

\section{Accounting Conservatism}

Accounting conservatism is expected to decrease post-IFRS. 5 frequencies of study on accounting conservatism are found (2.59\% of the total), with 2 frequencies of no effect (40.00\%), 2 frequencies of positive effect $(40.00 \%)$, and 1 frequency of negative effect (20.00\%).

Using IFRS as dummy variable, it is found that accounting conservatism decreases, as proven by the lower profit reporting (Hartanto, et al, 2013). However, IFRS as dummy variable also show other results, e.g. 1 frequencies of no effect, 1 frequency of positive effect, and 1 frequency of negative effect.

The implementation of fair value principle in IFRS is expected to make the financial information more neutral (in timeliness of good news and bad news acknowledgement) and more relevant, under the current economic condition. However, in studies that use IFRS adoption year as the dividing time line for pre-post comparison shows no difference in accounting conservatism before and after IFRS implementation.

\section{Stock return and stock risk}

With the implementation of IFRS convergence, it is expected that share return increases and share risk decreases. Studies on share return and risk are found in 5 frequencies (2.59\% of the total). 3 frequencies of share return show no effect and 2 frequencies of share risk show negative effect. In other words, a decrease in share risk is found, but there is no change in share return.

The adoption of PSAK 50 and 55 is expected to eradicate any opportunity for the management to engineer financial report because both PSAK requires bank to determine credit provision based on historical data of incurred loss, in which the 
reference data should be at least 3 years old. Previously, the determination is based on expectation loss, which allows banks to amass huge amount of provision if the manager think that their credit default is great. The adoption of PSAK 50 and 55 reduces the share risk, indicating that the accounting information is more relevant to be used as the basis for decision making, even though there is no share return found (Puspitarini, Hariyanto, Pinasti, 2014).

\section{Information Assymetry}

With the implementation of IFRS convergence, it is expected that information asymmetry decreases. Studies on information asymmetry are found in 4 frequencies ( $2.07 \%$ of the total), with results showing negative effect and no effect ( 2 frequencies each).

The variable used in independent variable measurement is the condition of financial reporting prior to and following IFRS convergence. Studies that show information asymmetry, measured using bid ask spread, indicate lower difference between the highest purchasing price and the lowest selling price of shares. This means that IFRS adoption makes information in financial report has higher quality (Rohmah and Yuni, 2013; Edvandini, et al, 2014). Meanwhile, other studies that show no difference in information asymmetry may be due to factor analysis that does not cover all incentive evidence (Fitriany, et al, 2016).

\section{External Audit Fee}

IFRS as a standard with complex rules may affect the external audit fee that a company has to pay. Studies on information asymmetry are found in 3 frequencies $(1.55 \%$ of the total), all three with positive effect. It means that IFRS convergence affects the increase of external audit services cost.

The period of research, both 4 years and 12 years, shows similar result; i.e. audit cost increases after IFRS implementation. This is because the complexity of fair value implementation in PSAK standards that adopt IFRS (Cahyonowati, 2012; Suhantinar and Juliarto, 2014; Elfira and Farahmita, 2015). The variables used in the measurement is IFRS as dummy variable.

\section{Trading Volume Activity (TVA)}

Studies on TVA are found in 3 frequencies (1.55\% of the total), with results showing positive effect ( 1 frequency) and no effect ( 2 frequencies). The volume of share trading is expected to increase after IFRS adoption. This is proven by the positive reaction of investors to the information presented in IFRS-based financial report (Huda and Ghofar, 2015). However, investors have not shown any reaction on the adoption of IFRS in 3 days before the announcement (27-30 March 2012) and 3 days after the announcement (2-4 April 2012), as evident in the absence of change in trading volume (Sun, et al, 2014). Analysis of PSAK 13,16 , and 30 on trading volume activity (TVA) finds that there is no 
significant effect of the 2007 financial report publication on TVA (Maulana and Mukhlisin, 2011).

\section{Cost of capital}

Studies on cost of capital are found in 2 frequencies (1.04\% of the total), all two with negative effect. With the implementation of IFRS, it is expected that cost of capital will decrease. This is supported by Fitriany, et al (2016) and Agustini (2016), who show that cost of capital has negative correlation after IFRS implementation because fair value principle makes financial report more transparent.

\section{Foreign Direct Investment (FDI)}

Studies on FDI are found in 1 frequencies (0.52\% of the total), with results showing positive effect. The convenience of comparability of IFRS-based financial reports is expected to improve investment, particularly from foreign investors. This is also supported by Martani and Marbun's (2016) findings by using IFRS adoption level in measuring IFRS adoption level. They concluded that the level of IFRS implementation has positive infact on Foreign Direct Investment (FDI) flow.

\section{Stock volatility and market efficiency}

Studies on stock volatility and market efficiency are found in 1 frequencies each (1.04\% of the total). Implementation of IFRS affect the decrease in variance (volatility) of return, and show a more stable and more efficient market as indicated by random movement of return, unaffected by the previous day's return. This means that all information currently available is reflected in the price of shares (Libryani and Rossieta, 2015).

\section{Analyst forecast error and analyst following}

Studies on stock volatility and market efficiency are found in 1 frequencies each (1.04\% of the total). Accuracy of profit estimation performed by analyst forecast error does not show any changes due to IFRS adoption. The same thing applies for the number of analyst following (Siahaan and Farahmita, 2015).

Overall, the systematic literature review shows that impact of IFRS adoption has attracted many research publication in Indonesia. IFRS adoption and its impact to company's performance quality, accounting quality and earnings management are major issues being investigated by researchers.

\section{Conclusion}

Studies on IFRS convergence in Indonesia between 2010 and 2016 show a trend of increasing number of published article every year. This indicates that there is an increase in interest towards the implementation of IFRS standards in Indonesia. The analysis 
result show that the company analysis unit, positivism paradigm, empirical-quantitative method, and secondary data analysis approach are the most dominantly used in IFRS convergence studies in Indonesia. Classified into three categories, the published research articles on the effect of IFRS convergence studies in Indonesia are more dominant (53.66\%), compared to the studies on IFRS implementation and issues (23.17\%) and IFRS convergence development in Indonesia (23.17\%).

Out of the 193 frequency found in the studies on the effect of IFRS convergence in Indonesia, the concept of value-relevance $(25.39 \%)$ and profit management $(24.35 \%)$ are the most commonly found categories. In general, IFRS convergence has an implication on financial reporting quality increase, as shown by the increase of valuerelevance, earnings management, accounting information quality, earnings quality, and financial institution performance, as well as the decrease in information asymmetry, shares risk, and cost of capital.

The varied results on IFRS convergence effect may be caused by several factors, such as the use of IFRS measurement variables, period of research, or number of sample. From several articles that discuss policies, future researches should delve in-depth in undiscussed PSAK (beside PSAK 5, PSAK 13, PSAK 16, PSAK 19, PSAK 22, PSAK 30, PSAK 46, PSAK 50, PSAK 55), PSAK that are discussed during the convergence process that it is relevant to review them today (PSAK 14, PSAK 26, PSAK 38, PSAK 51), or PSAK that are revised and newly implemented, such as PSAK 3, PSAK 24, PSAK 58, and PSAK 60 which are effective since 28 September 2016.

The implication of this study is that the implementation of fair value concept in IFRS standards has been utilized very well by companies in Indonesia. By selecting appropriate recording method with fair value concept that suits the company, the generated information becomes better and the stakeholders will have higher quality information.

The limitation of this study has to do with the difficulties of obtaining complete research articles, which affect the total number of final sample. Not all required information can be obtained from the abstract, which means that the complete research article is needed for the analysis. Future researches are expected to use greater number of sample so that the conclusion can be generalized more.

Another limitation of the study is the inconsistency of using SNA conference proceedings instead of just academic journal publications. As the conference proceedings often perceived as less rigorous than the journals, however the use of SNA conference proceedings in this paper has improved the quantity of the sample. SNA is also one of most competitive accounting conference in Indonesia, thus every year the conference invites good quality paper in par with many national journal publications. 


\section{Appendix}

Table A1 Comparison of Research Results on The Effect of IFRS Convergence in Indonesia on Value-Relevance Based on Periods and Samples

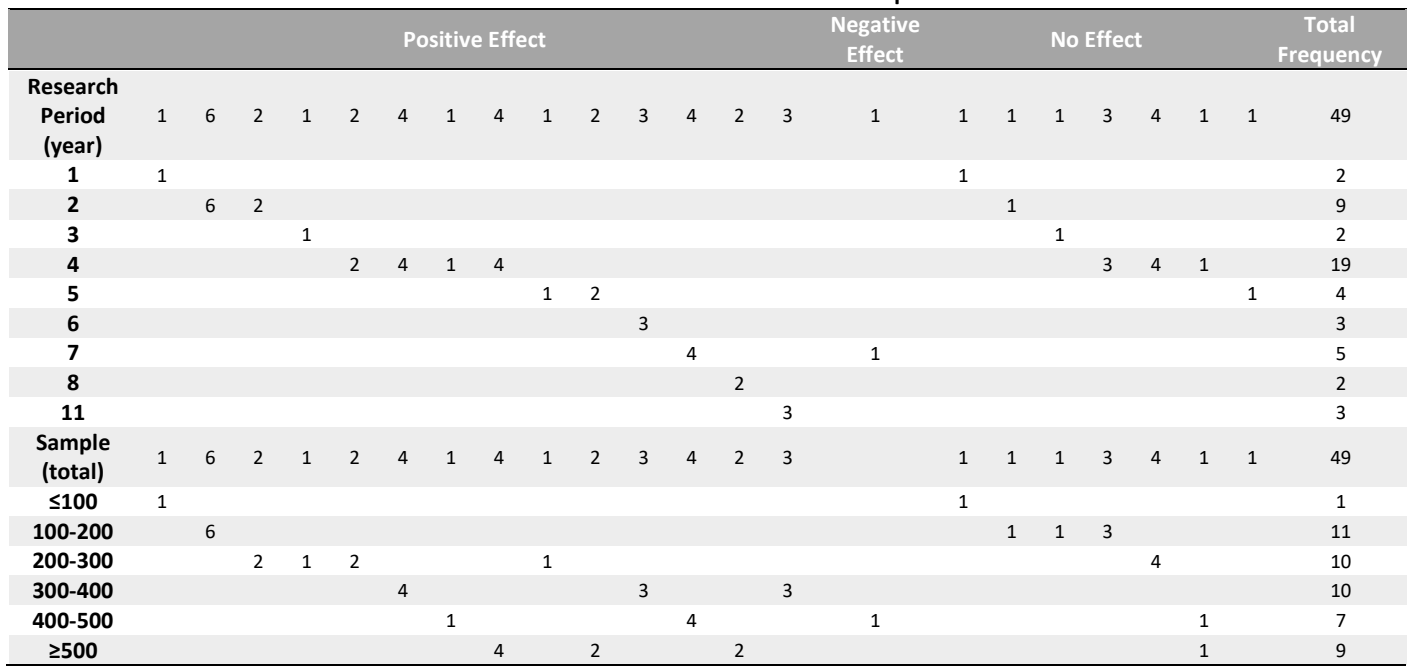

Table A2 Comparison of Research Results on The Effect of IFRS Convergence in Indonesia on Earnings Management Based on Periods and Samples

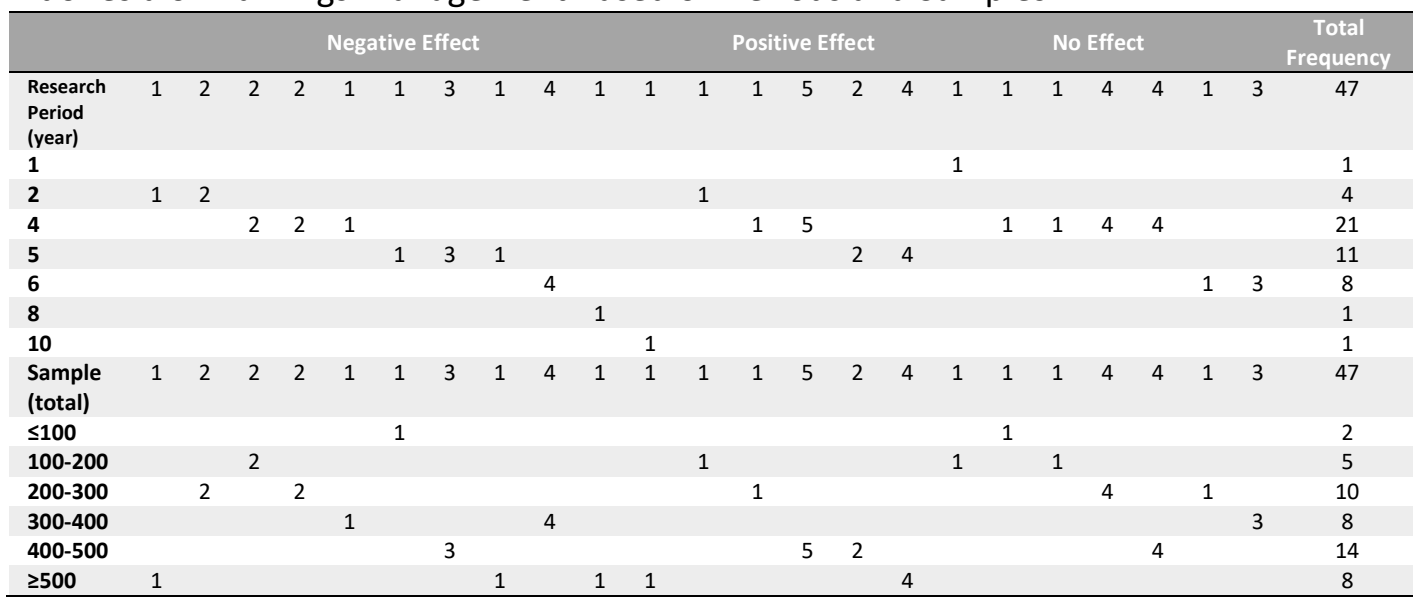

Table A3 Comparison of Research Results on The Effect of IFRS Convergence in Indonesia on Company Financial Performance Based on Periods and Samples

\begin{tabular}{|c|c|c|c|c|c|c|c|c|c|c|}
\hline & \multicolumn{3}{|c|}{ Positive Effect } & \multicolumn{2}{|c|}{ Negative Effect } & \multicolumn{4}{|c|}{ No Effect } & \multirow{2}{*}{$\frac{\text { Total Effect }}{24}$} \\
\hline $\begin{array}{c}\text { Research } \\
\text { Period (year) }\end{array}$ & 5 & 4 & 2 & 3 & 1 & 2 & 2 & 3 & 2 & \\
\hline 2 & 5 & & & 3 & & 2 & 2 & & & 12 \\
\hline 5 & & 1 & & & & & & 3 & 5 & 19 \\
\hline 8 & & & 2 & & 1 & & & & & 3 \\
\hline Sample (total) & 5 & 4 & 2 & 3 & 1 & 2 & 2 & 3 & 2 & 24 \\
\hline$\leq 100$ & & & 2 & & 1 & 2 & & & & 5 \\
\hline $100-200$ & 5 & 4 & & 3 & & & 2 & 3 & & 17 \\
\hline $200-300$ & & & & & & & & & 2 & 2 \\
\hline
\end{tabular}


Table A4 Comparison of Research Results on The Effect of IFRS Convergence in Indonesia on Accounting Information Quality Based on Periods and Samples

\begin{tabular}{|c|c|c|c|c|c|c|c|c|c|c|c|c|c|}
\hline Research & \multicolumn{8}{|c|}{ Positive Effect } & Negative Effect & \multicolumn{3}{|c|}{ No Effect } & $\begin{array}{l}\text { Total } \\
\text { Effect }\end{array}$ \\
\hline $\begin{array}{l}\text { Period } \\
\text { (year) }\end{array}$ & 1 & 5 & 3 & 1 & 1 & 1 & 1 & 1 & - & 1 & 3 & 1 & 19 \\
\hline 1 & 1 & & & & & & & & & & & & 1 \\
\hline 2 & & 5 & 3 & 1 & & & & & & 1 & 3 & & 13 \\
\hline 3 & & & & & 1 & & & & & & & & 1 \\
\hline 4 & & & & & & 1 & 1 & 1 & & & & & 3 \\
\hline 6 & & & & & & & & & & & & 1 & 1 \\
\hline $\begin{array}{c}\text { Sample } \\
\text { (total) }\end{array}$ & 1 & 5 & 3 & 1 & 1 & 1 & 1 & 1 & - & 1 & 3 & 1 & 19 \\
\hline$\leq 100$ & & 5 & & & & & & & & & & & 5 \\
\hline $100-200$ & & & 3 & & & & & & & 1 & & & 4 \\
\hline $200-300$ & & & & & & 1 & & & & & & & 1 \\
\hline $300-400$ & & & & 1 & 1 & & & & & & 3 & & 5 \\
\hline $400-500$ & & & & & & & 1 & & & & & & 1 \\
\hline$\geq 500$ & 1 & & & & & & & 1 & & & & 1 & 3 \\
\hline
\end{tabular}

Table A5 Comparison of Research Results on The Effect of IFRS Convergence in Indonesia on Earnings Quality Based on Periods and Samples

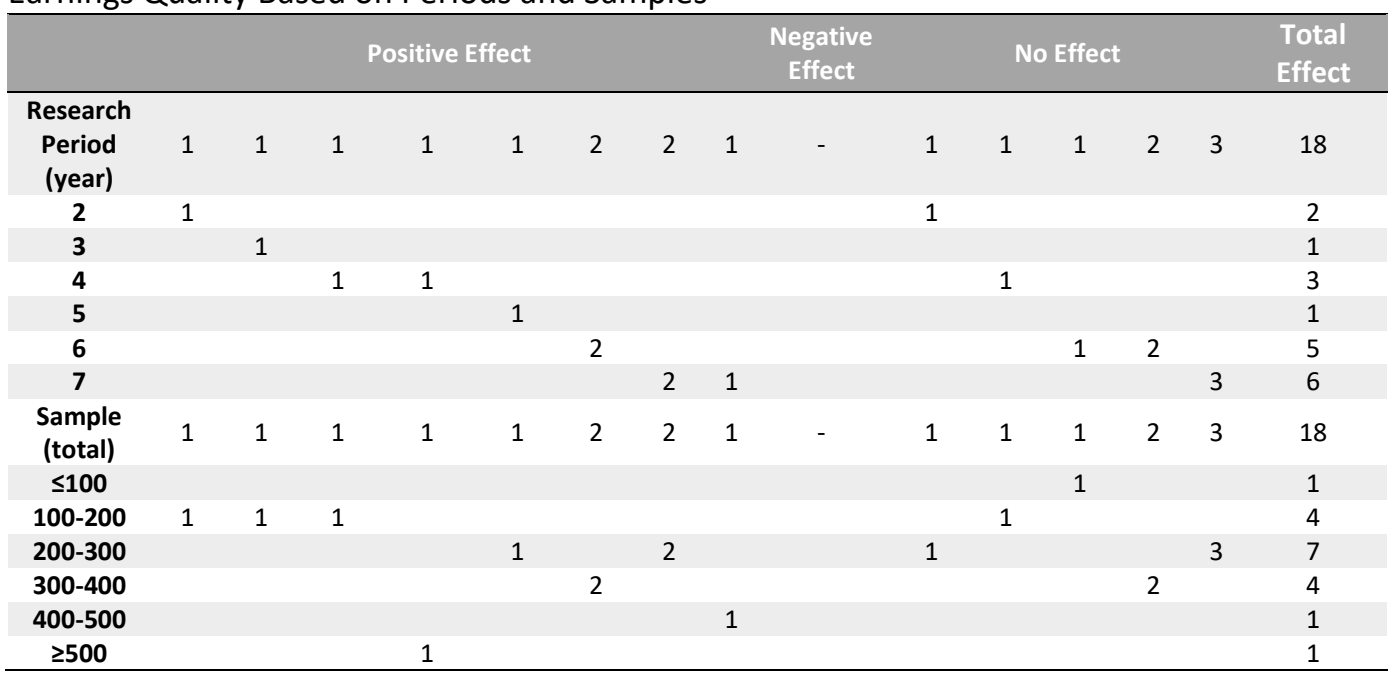

\section{References}

Agustini, A. T. (2016). The Effect of Firm Size and Rate of Inflation on Cost of Capital: The Role of IFRS Adoption in the World. Procedia-Social and Behavioral Sciences, 219, 47-54. https://doi.org/10.1016/j.sbspro.2016.04.031

Ahmed, K., Chalmers, K., \& Khlif, H. (2013). A meta-analysis of IFRS adoption effects. The International Journal of Accounting, 48(2), 173-217. https://doi.org/10.1016/i.intacc.2013.04.002

Ball, R. (2006). International Financial Reporting Standards (IFRS): pros and cons for investors. Accounting and business research, 36(sup1), 5-27. https://doi.org/10.1080/00014788.2006.9730040 
Balsari, C. K., \& Varan, S. (2014). IFRS implementation and studies in Turkey. Accounting and Management Information Systems, 13(2), 373. Retrieved from https://www.researchgate.net/publication/291336463_IFRS_Implementation_and S tudies in Turkey

Barth, M. E., Landsman, W. R., \& Lang, M. H. (2008). International accounting standards and accounting quality. Journal of accounting research, 46(3), 467-498. https://doi.org/10.1111/j.1475-679X.2008.00287.x

Basu, S. (1997). The conservatism principle and the asymmetric timeliness of earnings. Journal of accounting and economics, 24(1), 3-37. https://doi.org/10.1016/S01654101(97)00014-1

Callao, S., \& Jarne, J. I. (2010). Have IFRS affected earnings management in the European Union?. Accounting in Europe, 7(2), 159-189. https://doi.org/10.1080/17449480.2010.511896

Cahyonowati, N. (2012). Studi Eksploratori Hubungan Antara Konvergensi IFRS Dengan Biaya Audit. Indonesian Journal of Accounting and Auditing, 16(2). https://www.neliti.com/id/publications/95893/studi-eksploratori-hubungan-antarakonvergensi-ifrs-dengan-biaya-audit

Christensen, H. B., Lee, E., \& Walker, M. (2007). Cross-sectional variation in the economic consequences of international accounting harmonization: The case of mandatory IFRS adoption in the UK. The International Journal of Accounting, 42(4), 341-379. https://doi.org/10.1016/i.intacc.2007.09.007

Christensen, H. B., Lee, E., Walker, M., \& Zeng, C. (2015). Incentives or standards: What determines accounting quality changes around IFRS adoption?. European Accounting Review, 24(1), 31-61. https://doi.org/10.1080/09638180.2015.1009144

Collins, D. W., Maydew, E. L., \& Weiss, I. S. (1997). Changes in the value-relevance of earnings and book values over the past forty years. Journal of accounting and economics, 24(1), 39-67. https://doi.org/10.1016/S0165-4101(97)00015-3

Cuijpers, R., \& Buijink, W. (2005). Voluntary adoption of non-local GAAP in the European Union: A study of determinants and consequences. European accounting review, 14(3), 487-524. https://doi.org/10.1080/0963818042000337132

Daske, H. (2006). Economic benefits of adopting IFRS or US - GAAP - have the expected cost of equity capital really decreased?. Journal of Business Finance \& Accounting, 33(3-4), 329-373. https://doi.org/10.1111/j.1468-5957.2006.00611.x

Daske, H., Hail, L., Leuz, C., \& Verdi, R. (2008). Mandatory IFRS reporting around the world: Early evidence on the economic consequences. Journal of accounting research, 46(5), 1085-1142. https://doi.org/10.1111/j.1475-679X.2008.00306.x

DSAK-IAI. 2015. Kerangka Konseptual Pelaporan Keuangan. Ikatan Akuntan Indonesia.

Dewi, R. R., \& Kaseh, N. (2011). Pengaruh Konvergensi IFRS Terhadap Kualitas Laporan Keuangan Pada Perusahaan Non keuangan Yang Terdaftar Di Bursa Efek Indonesia. Media Riset Akuntansi, Auditing \& Informasi, 11(2), 29-62. http://dx.doi.org/10.25105/mraai.v11i2.618

Edvandini, L., Subroto, B., \& Saraswati, E. (2014). Telaah Kualitas Informasi Laporan Keuangan dan Asimetri Informasi Sebelum dan Setelah Adopsi IFRS. Jurnal Akuntansi Multiparadigma, 5(1), 88-95. http://dx.doi.org/10.18202/jamal.2014.04.5008

Elfira, \& Farahmita, A. 2015. Analisis Pengaruh Konvergensi IFRS Terhadap Biaya Jasa Audit: Studi Lintas Negara di ASEAN. SNA 18 Medan. Retrieved from https://adoc.tips/download/analisis-pengaruh-konvergensi-ifrs-terhadap-biaya-jasaaudit.html

Eng, J. N., \& Tri, W. E. (2012). Panduan Praktis Standar Akuntansi Kenangan Berbasis IFRS Edisi 2. Jakarta: Salemba Empat. 
Fitriany, Utama, S., Farahmita, A., \& Anggraita, V. 2016. Economic Consequences of IFRS Adoption in Indonesia. American Journal of Economics 6(1): 79-85 (2016) Scientific and Academic Publishing. http://10.5923/i.economics.20160601.10

Gassen, J., \& Sellhorn, T. (2006). Applying IFRS in Germany: Determinants and consequences. Germany: Determinants and Consequences (July 2006). https://doi.org/10.2139/ssrn. 906802

Hartanto, T., Januarsi, Y., \& Sabarudin. 2013. IFRS Adoption, Accounting Conservatism, and Examination on Moderating Effect of Woman Existance in Audit Committee. SNA 16 Manado.

Holthausen, R. W., \& Watts, R. L. (2001). The relevance of the value-relevance literature for financial accounting standard setting. Journal of accounting and economics, 31(1-3), 3-75. https://doi.org/10.1016/S0165-4101(01)00029-5

Huda, M. E. (2016). The Comparative Analysis Of Ifrs Adoption Through Earnings Response Coefficient And Conservative Principle: Case Study In Asean Countries. Jurnal Ilmiah Mahasiswa FEB, 4(1). Retrieved from https://jimfeb.ub.ac.id/index.php/jimfeb/article/view/2543

Iswaraputra, N., \& Farahmita, A. (2013). Dampak Adopsi IFRS pada PSAK terhadap Relevansi Nilai Goodwill: Studi Empiris di Bursa Efek Indonesia. Depok: Penelitian Fakultas Ekonomi Universitas Indonesia.

Khomsatun, S. (2016). Penerapan pengukuran nilai wajar PSAK-konvergensi IFRS dan dampaknya pada pilihan kebijakan akuntansi di Indonesia. Jurnal Riset Akuntansi dan Keuangan, 4(2), 967-984. http://doi.org/10.17509/jrak.v4i2.4031

Lang, M., Raedy, J. S., \& Wilson, W. (2006). Earnings management and cross listing: Are reconciled earnings comparable to US earnings?. Journal of Accounting and Economics, 42(1-2), 255-283. https://doi.org/10.1016/i.jacceco.2006.04.005

Lee, E., Walker, M., \& Christensen, H. B. (2008). Mandating IFRS: its impact on the cost of equity capital in Europe. Certified Accountants Educational Trust. https://doi.org/10.2308/jiar.2010.9.1.58

Libryani, R. M., \& Rossieta, H. 2015. Volatilitas Imbal Hasil dan Efisiensi Pasar Setelah Konvergensi PSAK-IFRS. SNA 18 Medan.

Lourenço, I. M. E. C., \& Branco, M. E. M. D. A. C. D. (2015). Main consequences of IFRS adoption: Analysis of existing literature and suggestions for further research. Revista Contabilidade \& Finanças, 26(68), 126-139. http://dx.doi.org/10.1590/1808$\underline{057 \times 201500090}$

Lubis, F., Basri, Y. M., \& Agusti, R. (2015). Analisis Pengaruh Penerapan IFRS, opini Audit, ukuran KAP, dan Profitabilitas terhadap Keterlambatan Penyampaian Laporan Keuangan: Studi Empiris pada Perusahaan Manufaktur Sektor Perdagangan, Jasa \& Investasi yang Terdaftar di Bursa Efek Indonesia. Jurnal Online Mahasiswa Fakultas Ekonomi Universitas Riau, 2(2). Retrieved from https://jom.unri.ac.id/index.php/JOMFEKON/article/view/9565

Martani, D., \& Marbun, F. 2016. Analisis Pengaruh Tarif Pajak dan Adopsi IFRS Terhadap Foreign Direct Investment (FDI) Pada Negara-Negara Berkembang di Asia. SNA 19 Lampung. Retrieved from https://ppa-feui.com/artikel/analisis-pengaruh-tarif-pajakdan-adopsi-ifrs-terhadap-foreign-direct-investment-fdi-pada-negara-negaraberkembang-di-asia/

Maulana, A., \& Mukhlisin, M. (2014). Analisa dampak konvergensi ifrs ke dalam psak 13, 16, dan 30 terhadap aktivitas perdagangan saham perusahaan yang terdaftar di bursa efek indonesia. Taækia Islamic Finance and Business Review, 6(2). Retrieved from https://media.neliti.com/media/publications/271292-analisa-dampak-konvergensiifrs-ke-dalam-7bce8e16.pdf 
Nurazmi, Handajani, L., \& Effendy, L. 2015. Dampak Adopsi IFRS Terhadap Manajemen Laba serta Peran Mekanisme Corporate Governance Pada Perbankan Indonesia. SNA 18 Medan. Retrieved from http://ejournal.unp.ac.id/students/index.php/akt/article/view/2984

Pratiwi, C. W., \& Tesniwati, R. (2013). Pengaruh Penerapan Ifrs terhadap Kinerja Bank melalui Tata Kelola Perbankan yang Baik. Prosiding PESAT, 5. Retrieved from https://media.neliti.com/media/publications/171696-ID-pengaruh-penerapan-ifrsterhadap-kinerja.pdf

Puspitarini, Hariyanto, W. E., \& Pinasti, M. 2014. Return dan Risiko Saham, Perataan Laba Pada Era Konvergensi International Financial Reporting Standards (IFRS). SNA 17 Mataram. Retrieved from https://www.coursehero.com/file/17845120/006/

Rohmah, A., \& Yuni, N. S. (2013). Dampak Penerapan Standar Akuntansi Keuangan (SAK) Pasca Adopsi IFRS terhadap Relevansi Nilai dan Asimetri Informasi. Simposium Nasional Akuntansi XVI Manado. Retrieved from http://pdeb.fe.ui.ac.id/?p=5026

Saito, M., \& Mayangsari, S. 2011. The Effect of IFRS Implementation on Earnings Quality in Indonesia. Annual research bulletin of Osaka Sangyo University, Grant-in-Aid for Scientific Research (B) No.22402053, FY20102013 in Japan Osaka Sangyo University. Retrieved from https://journal.osaka-sandai.ac.jp/result/pdf.php?ipdf $=608$

Siahaan, E. R. U., \& Farahmita, A. 2015. Pengaruh Tingkat Penegakan Aturan di Bidang Audit dan Akuntansi Terhadap Hubungan antara Adopsi IFRS dengan Prakiraan Laba Analis dan Analyst Following. SNA 18 Medan.

Silitonga, K., \& Farahmita, A. (2015). Pengaruh Kepemilikan Investor Institusional Terhadap Hubungan Antara Konvergensi IFRS dengan Waktu Terbitnya Laporan Keuangan di Indonesia. Simposium Nasional Akuntansi, 18.

Sitopu, A. S. W., \& Wardhani, R. 2014. Dampak Pengimplementasian IFRS Terhadap Kualitas Laporan Keuangan di Indonesia: Studi Atas PSAK 30 Tentang Sewa. SNA 17 Mataram.

Suhantinar, T. N., \& Juliarto, A. (2014). Pengaruh Konvergensi IFRS dan Client Attributes terhadap Penetapan Biaya Audit Eksternal (Doctoral dissertation, Fakultas Ekonomika dan Bisnis). Retrieved from https://ejournal3.undip.ac.id/index.php/accounting/article/view/10208

Sun, Y., Steelyana, E., \& Cahyadi, Y. (2014). Market Reaction to the Adoption of International Financial Reporting Standard in Indonesia. Binus Business Review, 5(2), 466-472. http://dx.doi.org/10.21512/bbr.v5i2.1005

Van Tendeloo, B., \& Vanstraelen, A. (2005). Earnings management under German GAAP versus IFRS. European Accounting Review, 14(1), 155-180. https://doi.org/10.1080/0963818042000338988

Wahyuni, E. T. (2011). The accountant perceptions of the IFRS convergence plan in Indonesia. Jumal Reviu Akuntansi dan Keuangan, 1(2), 85-96.

Weerakkody, V., Dwivedi, Y. K., \& Irani, Z. (2009). The diffusion and use of institutional theory: a cross-disciplinary longitudinal literature survey. Journal of Information Technology, 24(4), 354-368. https://doi.org/10.1057/jit.2009.16

Widyawati, A. A., \& Anggraita, V. (2013). Pengaruh Konfergensi IFRS Efektif Tahun 2011, Kompleksitas Akuntansi, dan Probabilitas Kebangkrutan Perusahaan Terhadap Timeless dan Manajemen Laba. Simposium Nasional Akuntansi XVI, 721-755.

Wijayanti, G. A., \& Rusiti, C. H. (2014). Analisis Manajemen Laba di Tingkat Segmen Sebelum dan Sesudah Penerapan Adopsi IFRS 8 menjadi PSAK 5 (2009) pada Perusahaan Manufaktur yang Terdaftar di BEI. Jurnal Ekonomi Akuntansi, 1-13. Retrieved from http://e-journal.uajy.ac.id/6106/1/jurnal.pdf 
Yanuar, H. (2013). Analisis Dampak Konvergensi IFRS Tahap Implementasi Pada Laporan Keuangan Perusahaan-Perusahaan Sektor Aneka Industri Yang Listing Di Bursa Efek Indonesia. Jurnal Audit dan Akuntansi Fakultas Ekonomi (JAAKFE), 2(1). Retrieved from http://jurnal.untan.ac.id/index.php/jaakfe/article/view/8993

Yurisandi, T., \& Puspitasari, E. (2015). Financial Reporting Quality-Before and After IFRS Adoption Using NiCE Qualitative Characteristics Measurement. Procedia-Social and Behavioral Sciences, 211, 644-652. https://doi.org/10.1016/j.sbspro.2015.11.091

Zeghal, D., Chtourou, S. M., \& Fourati, Y. M. (2012). The effect of mandatory adoption of IFRS on earnings quality: Evidence from the European Union. Journal of International Accounting Research, 11(2), 1-25. https://doi.org/10.2308/jiar-10221 